\title{
Induksi Akar dan Tunas Setek Batang Tanaman Pohpohan (Pilea trinervia Wight) dalam Media Air dengan Perlakuan IBA dan Aerasi
}

\section{Vegetative propagation of Pohpohan (Pilea trinervia Wight) in water media with aeration and IBA Treatment}

\author{
Katerin Ninariyani, Darda Efendi* dan E. Gunawan \\ Departemen Agronomi dan Hortikultura, Fakultas Pertanian, Itntitut Pertanian Bogor \\ (Bogor Agricultural University), Jl. Meranti, Kampus IPB Darmaga, Bogor 16680, Indonesia \\ Telp.\&Faks.62-251-8629353 e-mail agronipb@indo.net.id \\ *Penulis untuk korespondensi : dardaefendi@yahoo.co.id
}

Disetujui 20 Agustus 2018 / Published online 19 September 2018

\begin{abstract}
The objective of this experiment was to identify the effect of aeration and plant growth hormone indol -3- butiryc acid (IBA) on shoot and root induction of Pilea trinervia Wight. Research conducted at Greenhouse of Center for Tropical Holticulture Studies IPB, Bogor from June to October 2016. Research was using factorial split-plot design with four replicatiotn and two factors. The first factor as main block was aeration consisted two treatments which are aeration and without aeration. The second factor as sub block was IBA hormone consisted four treatments $0.0,0.5,1.0$, and $2.0 \mathrm{mg} \mathrm{L}^{-1}$. The result showed that aeration and IBA hormone affect on percentage of cuttings budded, number of roots formed, root length, number of shoots formed, and shoot length but not affecting percentage of living plant cuttings and cuttings rooted. The best result of root induction can be achieved at without aeration treatment and IBA 0.5, 1.0, and $2.0 \mathrm{mgL}^{-1}$.
\end{abstract}

Keywords: aeration, growth, IBA, induction, Pilea trinervia

\begin{abstract}
ABSTRAK
Penelitian ini bertujuan untuk mempelajari pengaruh penggunaan aerasi dan hormon pertumbuhan tanaman Indol -3-butiryc acid (IBA) pada induksi tunas dan akar setek Pohpohan (Pilea trinervia Wight.) dalam media air. Penelitian dilaksanakan di Rumah Kaca Kebun Percobaan Pasir Kuda, Pusat Kajian Holtikultura Tropika (PKHT) IPB pada bulan Juni-Oktober 2016. Penelitian menggunakan rancangan splitplot dua faktor dengan empat ulangan. Faktor pertama sebagai petak utama adalah aerasi terdiri dari dua taraf yaitu aerasi dan tanpa aerasi. Faktor kedua sebagai anak petak adalah IBA dengan empat taraf konsentrasi yaitu $0.0,0.5,1.0$, dan $2.0 \mathrm{mg} \mathrm{L}^{-1}$. Hasil penelitian menunjukan bahwa perlakuan aerasi dan IBA berpengaruh terhadap persentase setek bertunas, jumlah akar, panjang akar, jumlah tunas, dan panjang tunas, namun tidak berpengaruh pada persentase setek hidup dan setek berakar. Kombinasi perlakuan tanpa aerasi dan IBA $0.5,1.0$, dan $2.0 \mathrm{mgL}^{-1}$ menghasilkan jumlah akar paling banyak.
\end{abstract}

Kata kunci : aerasi, IBA, induksi, pertumbuhan, Pilea trinervia 


\section{PENDAHULUAN}

Indonesia memiliki kekayaan alam yang melimpah. Berbagai keanekaragaman hayati tersedia termasuk tanaman-tanaman indigenes. Tanaman indigenes disebut juga sebagai tanaman lokal, merupakan tanaman yang telah beradaptasi dengan sangat baik di suatu daerah sehingga potetni dari tanaman tersebut terekspresi secara penuh (Somantri 2006). Tanaman-tanaman indigenes sangat potetnial untuk dijadikan alternatif bahan pangan kaya gizi selain sayuran budidaya namun, pemanfaatannya masih terbatas pada daerah tertentu dan kurang dikenal di daerah-daerah lainnya (Sutiarso, 2010) seperti pohpohan yang baru banyak dimanfaatkan di wilayah Jawa Barat sebagai lalaban daun. Kondisi ini berbeda dengan tanaman sayur budidaya yang sudah dikenal di pasaran dan memiliki harga yang cukup stabil.

$\begin{array}{crr}\text { Pohpohan } & \begin{array}{r}\text { mengandung } \\ \text { golongan }\end{array} & \begin{array}{r}\text { beberapa } \\ \text { senyawa }\end{array}\end{array}$ steroid/triterpenoid, alkaloid, dan flavonoid yang terdiri dari quercetin, kaempferol, myricetin, luteolin, spigenin, dan senyawa flavonoid lainnya (Amelia et al., 2006 , Andarwulan et al., 2010). Desmiati (2001) menyatakat bahwa pohpohan mengandung asam askorbat, fenol, $\alpha$ - tokoferol, $\beta$-karoten, dan serat pangan larut (SDF) yang tinggi. Beberapa penelitian juga menunjukan bahwa pohpohan memiliki manfaat sebagai anti bakteri Staphylococcus aureus (Khudry, 2014) dan anti diabetes (Rahayuningsih dan Amelia, 2015). Kandungan antioksidan pada pohpohan bermanfaat mengurangi akumulasi radikal bebas, menetralisir racun, mencegah inflamasi, dan mencegah penyakit degeneratif. Hal ini menjadikan pohpohan sangat potetnial untuk dikembangkan sebagai tanaman budidaya.

Pohpohan banyak dibudidayakan dan diproduksi secara tumpang sari melalui setek batang. Menurut Mahyar (1994) untuk pemenuhan kebutuhan bibit pohpohan dalam jumlah yang banyak dan dalam waktu yang singkat yaitu dengan teknik perbanyakan secara vegetatif, salah satunya dengan setek. Penelitian Muslimawati (2014) menunjukan bahwa bahan tanam setek pohpohan yang terbaik adalah tanaman yang berumur 4 bulan dan media terbaik yang dapat digunakan adalah kombinasi sekam dan kompos. Menurut Rahmawati (2014) pohpohan tumbuh dengan baik pada intetnitas naungan 55\% dengan pemupukan NPK (15-15-15) sebanyak $88.3 \mathrm{~kg}^{-1}$ ha sampai $104.5 \mathrm{~kg}^{-1}$ ha. Upaya pengembangan secara in vitro juga mulai dilakukan.

Induksi akar dan tunas pada penelitian ini dilakukan dengan mencoba memodifikasi media pertumbuhannya yaitu menggunakan media air yang ditambahkan hormon IBA untuk memacu perakarannya. Metode ini diharapkan dapat memacu pembentukan akar lebih cepat dibandingkan induksi pada media tanah maupun kultur jaringan. Penggunaan air sebagai media pertumbuhan telah dikenal sejak 1930-an sebagai metode "water culture" atau juga dikenal sebagai hidroponik atau nutriculture (Hoagland dan Arnon 1950). Metode nutriculture ini pernah dilakukan pada tanaman tomat dalam greenhouse dengan membandingkan pertumbuhannya dengan kondisi lapang biasa. Hasilnya tomat dalam media nutriculture menghasilkan rata-rata hasil yang lebih tinggi dibandingkan tomat pada kondisi lapang biasa. Media yang digunakan adalah air maka, aerasi sangat dibutuhkan. Penggunaan Aerasi diperlukan untuk menyediakan oksigen bagi tanaman. Kondisi media tumbuh yang kekurangan oksigen dapat menghambat pembentukan akar tanaman (Cerveny dan Gibson, 2005). Sedangkan penggunaan IBA dalam penelitian ini bertujuan untuk mempercepat pembentukan akar (Newton et al., 1992 , Cerveny dan Gibson, 2005). Menurut Nickell (1982), Kester et al. (1990), dan Larsen dan Guse (1997) IBA merupakan auksin komersial yang lebih banyak digunakan dibandingkan NAA karena menunjukan efektifitas yang lebih baik pada rentang dosis dan jenis tanaman yang luas.

Penelitian ini bertujuan untuk mempelajari pengaruh pemberian hormon IBA dan aerasi serta interaksinya terhadap induksi akar dan tunas setek batang tanaman pohpohan dalam media air. Hipotesis yang diajukan dalam penelitian ini antara lain adanya pengaruh aerasi dan kotnentrasi IBA serta interaksi keduanya terhadap terhadap parameter yang diamati pada induksi akar dan tunas setek batang pohpohan dalam media air.

\section{BAHAN DAN METODE}

Penelitian dilaksanakan di Rumah Kaca Kebun Percobaan Pasir Kuda, Pusat Kajian Holtikultura Tropika, Itntitut Pertanian Bogor. Pembuatan larutan stok IBA dilakukan pada bulan Mei 2016 di Laboratorium Pusat Kajian Holtikultura Tropika (PKHT), Baranangsiang, Itntitut Pertanian Bogor. Penelitian dilaksanakan pada bulan Juni 2016 hingga Oktober 2016. Bahan yang digunakan dalam penelitian ini adalah setek tanaman pohpohan (Pilea trinervia Wight) aksesi Ciapus yang diperoleh dari kebun petani di Ciapus, Bogor. Bahan lain yang digunakan adalah air sebagai media tumbuh, hipoklorit, dan hormon tanaman IBA dengan empat kotnentrasi yaitu 0.0, 0.5 , 1.0, dan $2.0 \mathrm{mgL}^{-1}$, serta pupuk daun Growmore $\mathrm{AB}$ dosis $2.0 \mathrm{mgL}^{-1}$. Alat yang 
digunakan yaitu baki plastik persegi panjang berukuran $40 \mathrm{~cm} \times 15 \mathrm{~cm} \times 10 \mathrm{~cm}$, air pump, styrofoam, selang plastik, pengatur udara, pipa aerasi, perlengkapan itntalasi listrik, tali, $\mathrm{pH}$ meter, penggaris, hygro-thermometer, paranet, alat tulis dan alat pendukung seperti cutter dan gunting.

Penelitian dilakukan dengan
menggunakan rancangan percobaan petak terbagi (Splitplot Design) dengan dua faktor perlakuan yaitu perlakuan aerasi pada dua taraf perlakuan yaitu non aerasi dan dengan aerasi sebagai petak utama dan perlakuan IBA sebagai anak petak pada empat taraf konsentrasi yaitu 0.0, 0.5 , 1.0, dan $2.0 \mathrm{mg} \mathrm{L}^{-1}$. Secara keseluruhan terdapat delapan kombinasi perlakuan dengan masing-masing kombinasi perlakuan diulang sebanyak empat kali menghasilkan 32 satuan percobaan. Setiap satuan percobaan terdapat 40 setek dan dipilih 15 tanaman secara acak sebagai contoh.

Pelaksanaan kegiatan diawali dengan itntalasi peralatan aerasi dan penyiapan media tanam. Media tanam yang digunakan adalah air tanah bersih ditambahkan larutan stok IBA $700 \mathrm{mg}$ $\mathrm{L}^{-1}$ sehingga kotntentrasinya menjadi $0.0,0.5,1.0$, dan $2.0 \mathrm{mg} \mathrm{L}^{-1}$. Setiap bak air diisi dengan media tanam 8-9 liter disesuaikan dengan panjang setek dan ruas setek. Udara dialirkan dari air pump ke dalam media untuk kelompok perlakuan aerasi. Penyiapan bahan tanam meliputi pemotongan ruas, sterilisasi dalam larutan hipoklorit $0.2 \%$, pengelompokan setek sesuai karakteristik yang sama menjadi empat kelompok yaitu setek dengan tiga ruas panjang, tiga ruas pendek, ruas lebih dari tiga, dan campuran ketiga karakter tersebut. Setek yang digunakan adalah bagian pangkal dan tengah batang pohpohan.

Kegiatan berikutnya adalah penempatan setek dalam media air melalui lubang styrofoam. Setek dikondisikan dalam media dengan satu ruas batang menyentuh air. Keseimbangan posisi setek dalam media air dijaga menggunakan tisu yang diletakan di sekeliling lubang styrofoam. Setek dengan empat karakter diatas dikelompokan masing-masing dalam ulangan yang sama. Kegiatan perawatan meliputi pemberian pupuk daun $2 \mathrm{mgL}^{-1}$ yang dilarutkan di dalam media setek pada 24 HSP , menjaga kesesuaian tinggi media dengan setek, keseimbangan aliran udara, dan pemberian naungan $2 \times 50 \%$. Pengamatan dilakukan pada tanaman contoh dengan peubah yang diamati adalah persentase setek bertunas (\%), persentase setek berakar (\%), persentase setek hidup (\%), karakter morfologi meliputi jumlah akar (satuan), panjang akar (cm), jumlah tunas (satuan), dan panjang tunas $(\mathrm{cm})$.
Pengamatan dilakukan setiap tiga hari sekali. Analisis sidik ragam menggunakan software SAS 9.0. Apabila hasil uji $\mathrm{F}$ nyata, maka dilanjutkan dengan uji jarak berganda Duncan (Duncan Multiple Range Test/DMRT) pada taraf 5\%.

\section{HASIL DAN PEMBAHASAN}

\section{Kondisi Umum}

Penelitian ini dilaksanakan dalam rumah kaca kebun percobaan pasir kuda PKHT IPB. Suhu dalam rumah kaca cukup tinggi. Suhu maksimumnya mencapai $35^{\circ} \mathrm{C}$ meski dalam naungan paranet $2 \times 50 \%$. Kelembapan minimum yang terukur pada hygrometer mencapai $45 \%$. Kondisi ini cukup kering untuk pertumbuhan tanaman pohpohan yang habitat aslinya adalah lahan-lahan basah yang lembab. Kondisi ini disiasati dengan menyediakan ember-ember berisi air terbuka dan penyiraman di sekitar bak-bak penelitian untuk menambah kelembapan dan menurunkan suhu di dalam rumah kaca.

Air yang digunakan sebagai media tanam merupakan air tanah. Pertumbuhan setek pohpohan cukup baik pada awal-awal penanaman namun, performa tanaman terus menurun. Perakaran tanaman mulai mengalami perubahan warna menjadi cokelat dan pembusukan di daerah perakaran dan pangkal setek setelah kurang lebih satu bulan. Batang setek juga mulai kehilangan turgornya diikuti dengan layu cabang dan matinya daun dimulai dari daun tertua. kondisi ini berbeda-beda pada tiap tanaman. Beberapa tanaman rusak lebih cepat dibandingkan dengan lainnya. Kondisi layunya pucuk diperparah dengan adanya serangan hama kutu putih (Paracoccus marginatus) yang cukup parah dan beberapa serangga lainnya yang tak dominan seperti ulat, belalang, dan ladybug (Coccinelidae).

Pembusukan daerah perakaran mengawali proses kematian setek. Proses pembusukan diawali dari bagian setek yang terendam air. Pembusukan ini menyebabkan setek patah dan patahan ini mengkontaminasi media air, menyebabkan air menjadi keruh dan kotor. Proses pembusukan ini juga melepaskan bau yang menyengat. Proses pembusukan juga dibarengi dengan penurunan turgor batang setek dan tunas, serta layunya daun. Tanaman yang telah mengalami pembusukan batang hingga bagian atas dan layu pucuk akan mengalami kematian setek. Beberapa setek mampu bertahan dengan merontokan daun dan tunas, dan menjaga turgor batang setek. Sedikit sekali setek yang mampu bertahan dan mampu menumbuhkan kembali akarnya. 


\section{Persentase Setek Bertunas dan Setek Berakar}

Persentase setek berakar dan setek bertunas dihitung dengan membandingkan jumlah setek berakar atau setek bertunas pada hari pengamatan dengan jumlah setek pada hari pengamatan kemudian dikalikan seratus persen. Rata-rata persen bertunas pada setek pohpohan dalam penelitian ini cukup tinggi mencapai lebih dari $80 \%$ pada 6 HSP (Hari Setelah Perlakuan) dan lebih dari $90 \%$ pada 12 HSP. Hasil uji F (tabel 1) menunjukan bahwa persentase setek berakar tidak berbeda nyata baik pada faktor aerasi maupun IBA dan interaksinya.

Persentase setek bertunas dalam penelitian ini cukup tinggi mencapai lebih dari $80 \%$ di seluruh percobaan pada pengamatan 12 HSP. Hasil uji $\mathrm{F}$ menunjukan aerasi berpengaruh nyata pada 12 HSP dan IBA berpengaruh sangat nyata pada 6,9, dan berpengaruh nyata pada 12 HSP. Perlakuan tanpa aerasi nyata lebih tinggi dibandingkan perlakuan tanpa aerasi pada 12 HSP dan perlakuan IBA $0.0 \mathrm{mgL}^{-1}$ nyata lebih tinggi dibandingkan perlakuan IBA lainnya pada 6 HSP. Perlakuan IBA 0.0 dan IBA $0.5 \mathrm{mgL}^{-1}$ menghasilkan persentase setek bertunas lebih tinggi dibandingkan perlakuan IBA lainnya dan pada 12 HSP, perlakuan IBA $0.0,0.5$ dan 1.0 $\mathrm{mgL}^{-1}$ tidak berbeda nyata dan perlakuan IBA 1.0 dan $2.0 \mathrm{mgL}^{-1}$ juga tidak berbeda nyata. Kesimpulan yang dapat diambil ialah bahwa perlakuan aerasi dan IBA tidak memberikan pengaruh pada parameter persentase setek berakar sedangkan perlakuan aerasi hanya berpengaruh nyata pada persentase setek bertunas pada 12 HSP dan IBA berpengaruh nyata terhadap persentase setek bertunas. Meski demikian, tidak ada interaksi dari kedua perlakuan pada dua parameter tersebut.

Tabel 1 Persentase setek bertunas dan setek berakar setek tanaman pohpohan pada 6, 9, dan 12 HSP

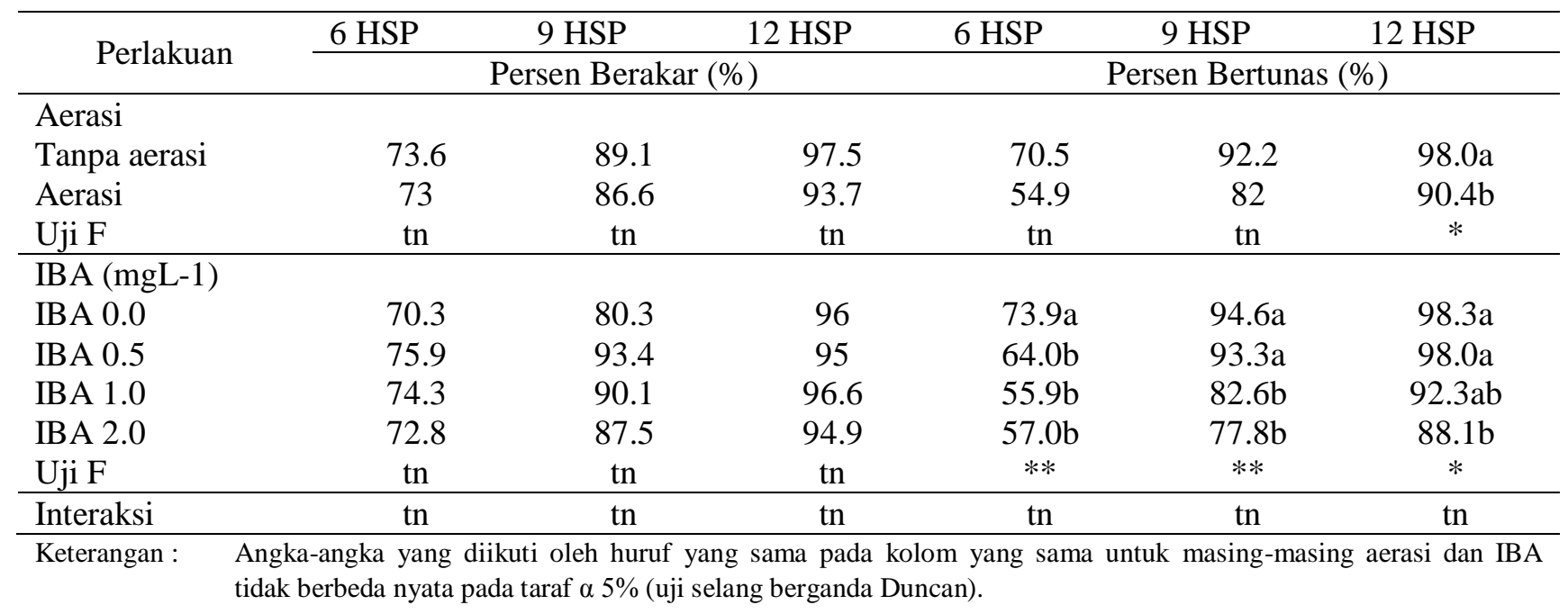

\section{Jumlah Akar}

Akar merupakan salah satu organ penting tanaman yang berfungsi untuk memenuhi kebutuhan air tanaman. Air diserap oleh akar-akar muda melalui epidermis akar (Zulkarnain, 2010). Jumlah akar dihitung pada tiap waktu pengamatan yaitu tiga hari sekali. Akar yang dihitung merupakan akar yang masih hidup meskipun akar mengalami browning namun belum mengalami pembusukan.

Hasil uji F (tabel 2) menunjukan perlakuan aerasi berpengaruh nyata terhadap jumlah akar yang dihasilkan setek pohpohan pada 24-42 HSP dan tidak berpengaruh nyata pada 6-18 HSP dan 48-60 HSP. Perlakuan tanpa aerasi menghasilkan rata-rata jumlah akar lebih banyak dibandingkan perlakuan aerasi. Penggunaan media tanpa aerasi menghasilkan rata-rata jumlah akar terbanyak pada 30 HSP dengan rata-rata akar terbentuk 45.3 sedangkan penggunaan media dengan aerasi menghasilkan rata-rata jumlah akar terbanyak pada 18 HSP dengan rata rata akar terbentuk 26.2 meskipun nilai ini tidak berbeda nyata dengan perlakuan tanpa aerasi pada hari yang sama.

Pemberian IBA berpengaruh sangat nyata terhadap jumlah akar pada 6-48 HSP dan nyata pada 54 HSP namun tidak berpengaruh nyata pada 60 HSP. Perlakuan dengan IBA rata-rata memiliki jumlah akar lebih banyak dibandingkan perlakuan IBA $0.0 \mathrm{mgL}^{-1}$ atau kontrol. Jumlah akar pada perlakuan IBA $0.5,1.0$ dan $2.0 \mathrm{mgL}^{-1}$ tidak berbeda nyata pada 12 sampai 30 HSP dan 60 HSP. Perlakuan IBA $0.0 \mathrm{mgL}^{-1}$ menghasilkan jumlah akar lebih sedikit dibandingkan perlakuan dengan IBA pada 12-36 HSP dan perlahan menjadi tidak nyata dengan perlakuan IBA 1.0 dan 2.0 $\mathrm{mgL}^{-1}$ pada $42 \mathrm{HSP}$, IBA 0.5 dan dan $1.0 \mathrm{mgL}^{-1}$ pada 54-60 HSP. Data pada tabel dua juga menunjukan pola semakin tinggi konsentrasi IBA 
semakin cepat jumlah akar maksimum dicapai oleh masing-masing taraf perlakuan IBA.

Interaksi sangat nyata pada 24-42 HSP dimana kedua perlakuan juga menunjukan uji $\mathrm{F}$ yang nyata. Kombinasi perlakuan yang tidak menggunakan IBA nyata lebih rendah dibandingkan perlakuan yang menggunakan IBA pada kelompok perlakuan aerasi yang sama. Hal ini dikarenakan IBA merupakan auksin sintetis yang perannya lebih dominan pada proses pembentukan akar. Kombinasi perlakuan tanpa aerasi dengan IBA 0.5, 1.0 dan $2.0 \mathrm{mgL}^{-1}$ menghasilkan akar yang tidak berbeda nyata jumlahnya (tabel 3).

Tabel 2. Pengaruh pemberian aerasi dan IBA terhadap jumlah akar setek tanaman pohpohan dalam media air

\begin{tabular}{|c|c|c|c|c|c|c|c|c|c|c|}
\hline \multirow{2}{*}{ Perlakuan } & \multicolumn{10}{|c|}{ Umur Setek (HSP) } \\
\hline & 6 & 12 & 18 & 24 & 30 & 36 & 42 & 48 & 54 & 60 \\
\hline Aerasi & \multicolumn{10}{|c|}{ Rata-rata jumlah akar } \\
\hline Tanpa aerasi & 2.2 & 24.3 & 34.6 & $42.4 \mathrm{a}$ & $45.3 \mathrm{a}$ & $42.4 \mathrm{a}$ & $36.5 \mathrm{a}$ & 31.7 & 29.1 & 20.9 \\
\hline Aerasi & 1.7 & 19.9 & 26.2 & $24.8 \mathrm{~b}$ & $20.4 \mathrm{~b}$ & $18.8 \mathrm{~b}$ & $18.7 \mathrm{~b}$ & 22.2 & 21.1 & 19.9 \\
\hline Uji F & tn & tn & tn & $*$ & $*$ & $*$ & $*$ & $\operatorname{tn}$ & tn & tn \\
\hline IBA (mgL-1) & \multicolumn{10}{|c|}{ Rata-rata jumlah akar } \\
\hline IBA 0.0 & $2.1 \mathrm{a}$ & $14.3 \mathrm{~b}$ & $20.0 \mathrm{~b}$ & $24.2 \mathrm{~b}$ & $26.3 b$ & $26.3 \mathrm{c}$ & $26.3 b$ & $26.9 \mathrm{~b}$ & $26.8 \mathrm{a}$ & 23.3 \\
\hline IBA 0.5 & $2.5 \mathrm{a}$ & $26.1 \mathrm{a}$ & $35.2 \mathrm{a}$ & $37.2 \mathrm{a}$ & $38.2 \mathrm{a}$ & $39.0 \mathrm{a}$ & $36.6 \mathrm{a}$ & $33.3 \mathrm{a}$ & $27.6 \mathrm{a}$ & 18.6 \\
\hline IBA 1.0 & $1.9 \mathrm{a}$ & $26.0 \mathrm{a}$ & $32.5 \mathrm{a}$ & $35.5 \mathrm{a}$ & $36.6 \mathrm{a}$ & $33.5 b$ & $29.0 \mathrm{~b}$ & $33.3 \mathrm{a}$ & $31.2 \mathrm{a}$ & 20.7 \\
\hline IBA 2.0 & $1.1 \mathrm{~b}$ & $22.5 \mathrm{a}$ & $34.8 \mathrm{a}$ & $39.8 \mathrm{a}$ & $36.5 \mathrm{a}$ & $33.0 \mathrm{~b}$ & $28.0 \mathrm{~b}$ & $22.3 \mathrm{c}$ & $19.6 b$ & 16.7 \\
\hline Uji F & $*$ & $* *$ & $* *$ & $* *$ & $* *$ & $* *$ & $* *$ & $* *$ & $*$ & tn \\
\hline Interaksi & $* *$ & tn & ** & ** & ** & ** & ** & ** & ** & ** \\
\hline
\end{tabular}

Keterangan: Angka-angka yang diikuti oleh huruf yang sama pada kolom yang sama untuk masing-masing aerasi dan IBA tidak berbeda nyata pada taraf $\alpha 5 \%$ (uji selang berganda Duncan).

Tabel 3 Interaksi aerasi dengan IBA terhadap jumlah akar setek pohpohan dalam media air

\begin{tabular}{cccccc}
\hline & \multicolumn{4}{c}{ Jumlah Akar } \\
\hline \multirow{2}{*}{ Aerasi } & IBA (mg L-1) & \multicolumn{4}{c}{ Umur (HSP) } \\
\cline { 2 - 5 } Tanpa Aerasi & 0 & 24 & 30 & 36 & 42 \\
& 0.5 & $38.9 \mathrm{c}$ & $33.4 \mathrm{c}$ & $33.0 \mathrm{~b}$ & $30.4 \mathrm{~b}$ \\
& 1 & $42.1 \mathrm{a}$ & $45.6 \mathrm{~b}$ & $46.9 \mathrm{a}$ & $43.9 \mathrm{a}$ \\
Dengan Aerasi & 2 & $42.3 \mathrm{a}$ & $51.9 \mathrm{a}$ & $50.5 \mathrm{a}$ & $42.2 \mathrm{a}$ \\
& 0 & $15.6 \mathrm{~d}$ & $17.0 \mathrm{~d}$ & $19.3 \mathrm{a}$ & $38.6 \mathrm{a}$ \\
& 0.5 & $34.0 \mathrm{~b}$ & $30.5 \mathrm{c}$ & $26.5 \mathrm{c}$ & $22.5 \mathrm{c}$ \\
& 1 & $24.7 \mathrm{c}$ & $19.3 \mathrm{~d}$ & $14.4 \mathrm{~d}$ & $11.6 \mathrm{~d}$ \\
& 2 & $27.8 \mathrm{c}$ & $22.5 \mathrm{~d}$ & $16.3 \mathrm{~d}$ & $14.7 \mathrm{~d}$ \\
\hline
\end{tabular}

Keterangan: $\quad$ Angka-angka yang diikuti oleh huruf yang sama pada kolom yang sama untuk kombinasi perlakuan aerasi dan IBA tidak berbeda nyata pada taraf $\alpha 5 \%$ (uji selang berganda Duncan).

\section{Panjang Akar}

Hasil uji F (tabel 4) menunjukan perlakuan aerasi berpengaruh terhadap panjang akar setek tanaman pohpohan pada 18-60 HSP. Media setek tanpa aerasi menghasilkan rata-rata akar yang lebih panjang dibandingkan media dengan perlakuan aerasi. Hal ini disebabkan kondisi akar pada media aerasi cenderung menggerombol dan menebal sehingga akar menjadi lebih pendek. Perlakuan IBA berpengaruh terhadap panjang akar pada seluruh pengamatan. Perlakuan IBA $0.0 \mathrm{mgL}^{-1}$ memiliki rata- rata akar lebih panjang dibandingkan dengan perlakuan IBA. Panjang akar pada perlakuan IBA 0.5 dan $1.0 \mathrm{mgL}^{-1}$ tidak berbeda nyata dan pemberian IBA $2.0 \mathrm{mgL}^{-1}$ menghasilkan akar yang lebih pendek dibandingkan perlakuan lainnya. Interaksi antar perlakuan berpengaruh nyata pada 12-18 HSP dan 30-42 HSP.

Secara umum dapat dilihat hubungan antara panjang akar dengan jumlah akar yakni, perlakuan dengan IBA menghasilkan jumlah akar yang lebih banyak namun memiliki panjang akar yang lebih pendek. Sementara itu perlakuan media tanpa IBA menghasilkan jumlah akar paling sedikit namun memiliki akar yang lebih panjang. Hal ini dapat disebabkan oleh induksi akar yang sangat cepat pada perlakuan IBA namun tanaman tidak cukup mendapatkan asupan nutrisi sehingga pertumbuhan akar menjadi tidak maksimal. Selain itu, menurut Hartmann dan Kester (1994), IBA dapat bersifat racun pada setek tanaman berkayu lunak dan menyebabkan pertumbuhan setek terhambat. 
Tabel 4 Pengaruh aerasi dan IBA terhadap panjang akar setek tanaman pohpohan dalam media air

\begin{tabular}{|c|c|c|c|c|c|c|c|c|c|c|}
\hline \multirow{2}{*}{ Perlakuan } & \multicolumn{10}{|c|}{ Umur Tanaman (HSP) } \\
\hline & 6 & 12 & 18 & 24 & 30 & 36 & 42 & 48 & 54 & 60 \\
\hline Aerasi & \multicolumn{10}{|c|}{ Rata-rata panjang akar $(\mathrm{cm})$} \\
\hline Tanpa Aerasi & 0.27 & 3.21 & $4.94 \mathrm{a}$ & $5.73 \mathrm{a}$ & $5.78 \mathrm{a}$ & $5.70 \mathrm{a}$ & $5.78 \mathrm{a}$ & $5.87 \mathrm{a}$ & $6.06 \mathrm{a}$ & $5.94 \mathrm{a}$ \\
\hline Aerasi & 0.21 & 1.87 & $2.29 b$ & $2.17 \mathrm{~b}$ & $2.18 \mathrm{~b}$ & $2.25 b$ & $2.45 b$ & $2.87 \mathrm{~b}$ & $2.66 \mathrm{~b}$ & $3.16 \mathrm{~b}$ \\
\hline Uji F & tn & $\operatorname{tn}$ & $*$ & $* *$ & $* *$ & $* *$ & $* *$ & $* *$ & $* *$ & $*$ \\
\hline IBA (mgL-1) & \multicolumn{10}{|c|}{ Rata-rata panjang akar $(\mathrm{cm})$} \\
\hline IBA 0.0 & $0.57 \mathrm{a}$ & $3.70 \mathrm{a}$ & $5.28 \mathrm{a}$ & $5.73 \mathrm{a}$ & $6.07 \mathrm{a}$ & $6.01 \mathrm{a}$ & $6.07 \mathrm{a}$ & $6.29 \mathrm{a}$ & $6.65 \mathrm{a}$ & $6.44 a$ \\
\hline IBA 0.5 & $0.22 b$ & $2.78 \mathrm{~b}$ & $3.60 \mathrm{~b}$ & $3.86 b$ & $3.94 b$ & $4.17 b$ & $4.29 b$ & $4.69 b$ & $4.42 b$ & $3.97 \mathrm{~b}$ \\
\hline IBA 1.0 & $0.12 b c$ & $2.30 \mathrm{c}$ & $3.39 \mathrm{~b}$ & $3.71 \mathrm{a}$ & $3.78 b$ & $3.82 \mathrm{~b}$ & $4.08 \mathrm{~b}$ & $5.21 \mathrm{~b}$ & $4.96 \mathrm{~b}$ & $3.85 \mathrm{~b}$ \\
\hline IBA 2.0 & $0.06 \mathrm{c}$ & $1.42 \mathrm{~d}$ & $2.41 \mathrm{c}$ & $2.83 \mathrm{c}$ & $2.93 \mathrm{c}$ & $3.01 \mathrm{c}$ & $3.23 \mathrm{c}$ & $3.07 \mathrm{c}$ & $2.73 \mathrm{c}$ & $2.62 \mathrm{c}$ \\
\hline Uji F & $* *$ & $* *$ & $* *$ & $* *$ & $* *$ & $* *$ & $* *$ & $* *$ & $* *$ & $* *$ \\
\hline Interaksi & tn & $* *$ & $*$ & tn & $*$ & $*$ & $* *$ & tn & tn & tn \\
\hline Keterangan : & \multicolumn{10}{|c|}{$\begin{array}{l}\text { Angka-angka yang diikuti oleh huruf yang sama pada kolom yang sama untuk masing-masing perlakuan } \\
\text { Aerasi dan IBA tidak berbeda nyata pada taraf } \alpha 5 \% \text { (uji selang berganda Duncan). }\end{array}$} \\
\hline \multicolumn{5}{|c|}{ Perlakuan } & \multicolumn{6}{|c|}{ Panjang Akar $(\mathrm{cm})$} \\
\hline \multirow{2}{*}{\multicolumn{2}{|c|}{ Aerasi }} & \multirow{2}{*}{\multicolumn{3}{|c|}{ IBA (mg L-1) }} & \multicolumn{6}{|c|}{ Umur (HSP) } \\
\hline & & & & & \multicolumn{2}{|c|}{30} & \multicolumn{2}{|c|}{36} & \multicolumn{2}{|c|}{42} \\
\hline \multirow{4}{*}{\multicolumn{2}{|c|}{ Tanpa Aerasi }} & \multicolumn{3}{|c|}{0} & \multirow{2}{*}{\multicolumn{2}{|c|}{$\begin{array}{l}7.44 \mathrm{a} \\
6.01 \mathrm{~b}\end{array}$}} & \multicolumn{2}{|c|}{$7.32 \mathrm{a}$} & \multicolumn{2}{|c|}{$7.04 a$} \\
\hline & & \multicolumn{3}{|c|}{0.5} & & & \multicolumn{2}{|c|}{$5.90 \mathrm{~b}$} & \multicolumn{2}{|c|}{$5.82 \mathrm{~b}$} \\
\hline & & \multicolumn{3}{|c|}{1} & \multicolumn{2}{|c|}{$5.42 \mathrm{~b}$} & \multirow{2}{*}{\multicolumn{2}{|c|}{$\begin{array}{l}5.50 \mathrm{~b} \\
4.17 \mathrm{c}\end{array}$}} & \multicolumn{2}{|c|}{$5.76 b$} \\
\hline & & \multicolumn{3}{|c|}{2} & \multicolumn{2}{|c|}{$4.30 \mathrm{c}$} & & & & \\
\hline \multirow{4}{*}{\multicolumn{2}{|c|}{ Dengan Aerasi }} & \multirow{2}{*}{\multicolumn{3}{|c|}{0}} & \multicolumn{2}{|c|}{$4.48 \mathrm{c}$} & 4.43 & & 4.7 & \\
\hline & & & & & 1.4 & & 1.61 & & & \\
\hline & & & 1 & & 1.4 & & 1.18 & & & \\
\hline & & & 2 & & 1.2 & & 1.13 & & & \\
\hline
\end{tabular}

Keterangan: Angka-angka yang diikuti oleh huruf yang sama pada kolom yang sama untuk kombinasi perlakuan Aerasi dan IBA tidak berbeda nyata pada taraf $\alpha 5 \%$ (uji selang berganda Duncan).

Interaksi antara perlakuan aerasi dengan IBA keduanya nyata pada 30-42 HSP . Hasil analisis interaksi menunjukan kombinasi perlakuan baik tanpa aerasi maupun aerasi dengan IBA $0.0 \mathrm{mgL}^{-1}$ menghasilkan akar yang lebih panjang dibandingkan kombinasi perlakuan lainnya pada masing-masing kelompok perlakuan aerasi yang sama. Kombinasi medium yang menghasilkan akar terpanjang ialah media tanpa aerasi dengan IBA $0.0 \mathrm{mgL}^{-1}$ (tabel 5). Penggunaan IBA baik pada kelompok tanpa aerasi maupun dengan aerasi, keduanya menunjukan penurunan nilai searah dengan peningkatan kotnentrasi IBA yang digunakan.

\section{Jumlah Tunas Aktual}

Pembentukan tunas merupakan salah satu respon tanaman terhadap sinyal kerusakan sehingga tanaman merespon dengan melakukan regenerasi sel dan memunculkan tunas. Jumlah tunas aktual merupakan jumlah tunas sebenarnya yang diamati pada setiap pengamatan. Hasil uji F (tabel 6) menunjukan bahwa perlakuan aerasi berpengaruh nyata pada jumlah tunas aktual yang dihasilkan pada 6, 30, dan 36 HSP dan tidak berpengaruh nyata pada 12, $18,24,42,48,54$, dan 60 HSP. Perlakuan IBA memberikan pengaruh yang berbeda nyata terhadap jumlah tunas aktual yang dihasilkan pada pengamatan 6-30 HSP dan 48 HSP serta tidak berbeda nyata pada 36, 42, 54, dan 60 HSP. Perlakuan IBA $0.0 \mathrm{mgL}^{-1}$ tidak berbeda nyata dengan perlakuan IBA 0.5 dan $1.0 \mathrm{mgL}^{-1}$ pada $18,24,30$, dan 48 HSP namun nyata lebih tinggi dibandingkan perlakuan IBA $2.0 \mathrm{mgL}^{-1}$. 
Tabel 6 Pengaruh aerasi dan IBA terhadap jumlah tunas setek tanaman pohpohan dalam media air

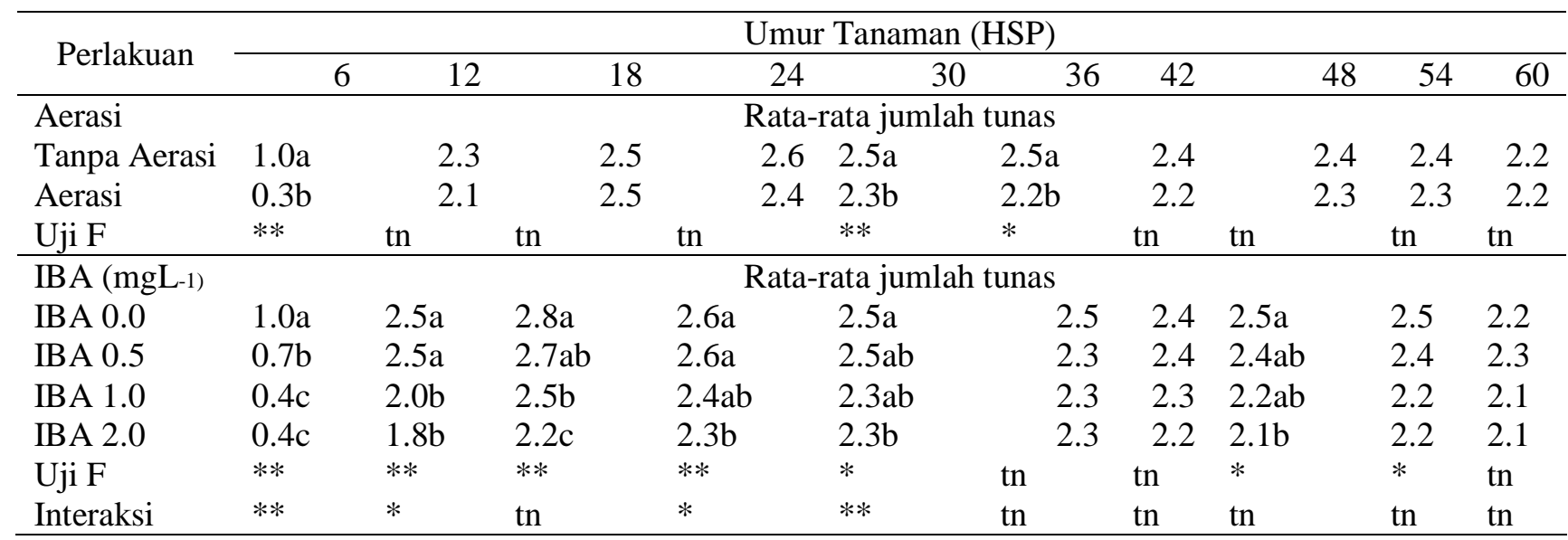

Keterangan: Angka-angka yang diikuti oleh huruf yang sama pada kolom yang sama untuk masing-masing perlakuan aerasi dan IBA tidak berbeda nyata pada taraf $\alpha 5 \%$ (uji selang berganda Duncan).

Tabel 7 Interaksi aerasi dengan IBA terhadap jumlah tunas setek pohpohan dalam media air

\begin{tabular}{lccc}
\hline & Perlakuan & & \multicolumn{2}{c}{ Jumlah Tunas } \\
\hline \multirow{2}{*}{ Aerasi } & \multirow{2}{*}{ IBA (mg L-1) } & 6 & Umur (HSP) \\
\cline { 3 - 4 } & 0 & $0.2 \mathrm{~d}$ & 30 \\
\hline Tanpa Aerasi & 0.5 & $0.2 \mathrm{~d}$ & $2.7 \mathrm{a}$ \\
& 1 & $0.1 \mathrm{~d}$ & $2.5 \mathrm{abc}$ \\
& 2 & $0.1 \mathrm{~d}$ & $2.5 \mathrm{ab}$ \\
Dengan Aerasi & 0 & $1.6 \mathrm{a}$ & $2.3 \mathrm{abc}$ \\
& 0.5 & $1.2 \mathrm{~b}$ & $2.6 \mathrm{a}$ \\
& 1 & $0.7 \mathrm{c}$ & $2.1 \mathrm{bc}$ \\
& 2 & $0.7 \mathrm{c}$ & $2.0 \mathrm{c}$ \\
\hline
\end{tabular}

Keterangan: Angka-angka yang diikuti oleh huruf yang sama pada kolom yang sama untuk kombinasi perlakuan Aerasi dan IBA tidak berbeda nyata pada taraf $\alpha 5 \%$ (uji selang berganda Duncan).

Interaksi kedua perlakuan nyata pada 6 dan 30 HSP. Kombinasi perlakuan aerasi dengan IBA $0.0 \mathrm{mgL}^{-1}$ nyata paling tinggi pada $6 \mathrm{HSP}$. Kombinasi IBA pada seluruh taraf perlakuan dengan media tanpa aerasi semuanya tidak berbeda nyata dengan kombinasi aerasi dengan IBA 0.0 dan $0.5 \mathrm{mgL}^{-1}$ (tabel 7).

Seluruh perlakuan hanya menghasilkan rata-rata jumlah tunas lebih kurang sebanyak dua tunas namun, jika dilihat nilai desimal yang mengikutinya maka dapat disimpulkan bahwa jumlah tunas aktual yang dihasilkan semakin sedikit seiring dengan bertambahnya kotnentrasi
IBA yang digunakan. Menurut Hartman, et al (1997) aplikasi IBA pada konsentrasi tinggi dan aplikasi IBA pada basal dapat menghambat pembentukan dan perkembangan tunas. IBA ditratnlokasikan ke bagian pucuk tanaman dan menghambat pembentukan tunas dengan meningkatkan sintesa etilen pada setek. Hasil penelitian Tabel et al (1991) pada kultur jaringan tanaman melon menggunakan auksin 2,4D , IAA, dan NAA juga menunjukan bahwa pembentukan tunas terjadi pada kotnentrasi auksin rendah $0.0-1.0 \mathrm{mgL}^{-1}$. 
Tabel 8. Pengaruh aerasi dan IBA terhadap panjang tunas setek pohpohan dalam media air

\begin{tabular}{|c|c|c|c|c|c|c|c|c|c|c|}
\hline \multirow{2}{*}{ Perlakuan } & \multicolumn{10}{|c|}{ Umur Tanaman (HSP) } \\
\hline & 6 & 12 & 18 & 24 & 30 & 36 & 42 & 48 & 54 & 60 \\
\hline Aerasi & \multicolumn{10}{|c|}{ Rata-rata panjang tunas $(\mathrm{cm})$} \\
\hline Tanpa Aerasi & 0 & 0.4 & 1.98 & 3.36 & 4.41 & $5.71 \mathrm{a}$ & $6.59 \mathrm{a}$ & $7.13 \mathrm{a}$ & $7.47 \mathrm{a}$ & $7.54 \mathrm{a}$ \\
\hline Aerasi & 0 & 0.29 & 1.3 & 2.4 & 3.26 & $4.04 b$ & $4.43 b$ & $4.87 \mathrm{~b}$ & $5.17 \mathrm{~b}$ & $5.26 \mathrm{~b}$ \\
\hline Uji F & tn & tn & tn & $\operatorname{tn}$ & $*$ & $*$ & $*$ & $*$ & $*$ & $*$ \\
\hline IBA (mgL-1) & \multicolumn{10}{|c|}{ Rata-rata panjang tunas $(\mathrm{cm})$} \\
\hline IBA 0.0 & 0 & $0.45 \mathrm{a}$ & $1.79 \mathrm{a}$ & $3.14 \mathrm{a}$ & $4.40 \mathrm{a}$ & $6.01 \mathrm{a}$ & $6.66 \mathrm{a}$ & $7.41 \mathrm{a}$ & $7.88 \mathrm{a}$ & $8.02 \mathrm{a}$ \\
\hline IBA 0.5 & 0 & $0.46 \mathrm{a}$ & $1.84 \mathrm{a}$ & $3.02 \mathrm{a}$ & $4.11 \mathrm{ab}$ & $5.15 \mathrm{ab}$ & $5.85 \mathrm{ab}$ & $6.38 b$ & $6.84 b$ & $6.87 b$ \\
\hline IBA 1.0 & 0 & $0.28 b$ & $1.64 \mathrm{a}$ & $2.92 \mathrm{a}$ & $3.77 \mathrm{~b}$ & $4.57 b$ & $5.23 \mathrm{bc}$ & $5.92 b$ & $6.13 b$ & $6.21 b$ \\
\hline IBA 2.0 & 0 & $0.20 \mathrm{~b}$ & $1.33 \mathrm{~b}$ & $2.54 b$ & $3.23 \mathrm{c}$ & $4.06 \mathrm{c}$ & $4.69 \mathrm{c}$ & $4.84 \mathrm{c}$ & $4.86 \mathrm{c}$ & $4.53 \mathrm{c}$ \\
\hline Uji F & $\operatorname{tn}$ & $* *$ & ** & $* *$ & $* *$ & $* *$ & $* *$ & $* *$ & $* *$ & $* *$ \\
\hline Interaksi & tn & tn & tn & $\operatorname{tn}$ & $* *$ & $* *$ & $* *$ & $* *$ & $* *$ & $* *$ \\
\hline
\end{tabular}

Tabel 9 Interaksi aerasi dengan IBA terhadap panjang tunas setek pohpohan dalam media air

\begin{tabular}{ccccccc}
\hline \multicolumn{2}{c}{ Perlakuan } & \multicolumn{5}{c}{ Panjang Tunas (cm) } \\
\hline \multirow{2}{*}{ Aerasi } & \multirow{2}{*}{ IBA (mg L-1) } & \multicolumn{5}{c}{ Umur (HSP) } \\
\cline { 3 - 7 } & 0 & $5.83 \mathrm{a}$ & $6.57 \mathrm{a}$ & 78 & 54 & 60 \\
\hline Tanpa Aerasi & 0.5 & $6.14 \mathrm{a}$ & $7.09 \mathrm{a}$ & $7.70 \mathrm{a}$ & $7.66 \mathrm{ab}$ & $7.71 \mathrm{a}$ \\
& 1 & $5.66 \mathrm{a}$ & $6.50 \mathrm{a}$ & $7.18 \mathrm{ab}$ & $7.61 \mathrm{ab}$ & $8.44 \mathrm{a}$ \\
& 2 & $5.22 \mathrm{a}$ & $6.16 \mathrm{a}$ & $6.20 \mathrm{~b}$ & $6.26 \mathrm{bc}$ & $5.96 \mathrm{~b}$ \\
\hline Dengan Aerasi & 0 & $6.21 \mathrm{a}$ & $6.76 \mathrm{a}$ & $7.46 \mathrm{ab}$ & $8.17 \mathrm{a}$ & $8.41 \mathrm{a}$ \\
& 0.5 & $4.05 \mathrm{~b}$ & $4.40 \mathrm{~b}$ & $4.78 \mathrm{c}$ & $5.02 \mathrm{c}$ & $5.16 \mathrm{bc}$ \\
& 1 & $3.10 \mathrm{c}$ & $3.22 \mathrm{c}$ & $3.55 \mathrm{~cd}$ & $3.55 \mathrm{~d}$ & $3.71 \mathrm{~cd}$ \\
& 2 & $2.48 \mathrm{c}$ & $2.72 \mathrm{c}$ & $2.87 \mathrm{~d}$ & $3.10 \mathrm{~d}$ & $2.93 \mathrm{~d}$ \\
\hline
\end{tabular}

Keterangan: Angka-angka yang diikuti oleh huruf yang sama pada kolom yang sama untuk masing-masing perlakuan aerasi dan IBA tidak berbeda nyata pada taraf $\alpha 5 \%$ (uji selang berganda Duncan).

Hasil uji F (tabel 9) menunjukan bahwa perlakuan aerasi berpengaruh nyata terhadap panjang tunas pada 36-60 HSP dan tidak berpengaruh nyata pada 6-30 HSP. Penggunaan media tanpa aerasi menghasilkan rata-rata tunas yang lebih panjang dibandingkan penggunaan aerasi. Menurut Jackson dan Colmer (2005) dan Sato et al. (2002) pada kondisi tergenang, etilen merupakan salah satu hormon tumbuhan yang berperan dalam pemanjangan sel dan pembelahan sel pada tanaman.

Pemberian IBA memberikan pengaruh nyata terhadap panjang tunas setek pohpohan kecuali pada 6 HSP dimana tunas pada setiap percobaan masih belum dapat diukur. Perlakuan IBA $0.0 \mathrm{mgL}^{-1}$ tidak berbeda nyata dengan IBA $0.5 \mathrm{mgL}^{-1}$ pada 6-42 HSP, dengan IBA $1.0 \mathrm{mgL}^{-1}$ pada 6,18 , dan 24 HSP namun sangat berbeda nyata dengan perlakuan IBA $2.0 \mathrm{mgL}^{-1}$. Pemberian IBA $2.0 \mathrm{mgL}^{-1}$ menghasilkan tunas yang lebih pendek dibandingkan perlakuan lainnya. Panjang tunas yang dihasilkan semakin menurun seiring peningkatan kotnentrasi IBA yang digunakan (tabel 9).

Interaksi kedua perlakuan nyata pada 3660 HSP. Hasil analisis interaksi menunjukan kombinasi perlakuan tanpa aerasi dengan IBA 0.5 $\mathrm{mgL}^{-1}$ tidak berbeda nyata dengan perlakuan IBA 0.0 dan $1.0 \mathrm{mgL}^{-1}$ pada $36-60 \mathrm{HSP}$, dengan IBA $2.0 \mathrm{mgL}^{-1}$ pada 36 dan $42 \mathrm{HSP}$, dan dengan kombinasi aerasi dan IBA $0.0 \mathrm{mgL}^{-1}$ pada 36-60 HSP. Panjang tunas paling pendek dihasilkan oleh kombinasi perlakuan aerasi dengan IBA 1.0 dan $2.0 \mathrm{mgL}^{-1}$ (tabel 10).

\section{Persentase Setek Hidup}

Perlakuan aerasi hanya berpengaruh nyata pada 12 dan 36 HSP sehingga secara keseluruhan dianggap perlakuan aerasi tidak berpengaruh terhadap persentase setek hidup. Rata-rata persen setek hidup pada perlakuan tanpa aerasi lebih tinggi dibandingkan perlakuan dengan aerasi. Perlakuan IBA juga tidak berpengaruh terhadap persentase setek hidup. Perlakuan IBA $0.0 \mathrm{mgL}^{-1}$ memiliki persentase setek hidup lebih besar dibandingkan perlakuan IBA lainnya dan perlakuan IBA $2.0 \mathrm{mgL}^{-1}$ memiliki persentase setek hidup paling rendah. Persentase setek hidup semakin menurun pada setiap pengamatan (tabel $10)$. 
Tabel 10. Pengaruh aerasi dan IBA terhadap persentase setek hidup setek tanaman pohpohan dalam media air

\begin{tabular}{|c|c|c|c|c|c|c|c|c|c|c|}
\hline \multirow{2}{*}{ Perlakuan } & \multicolumn{10}{|c|}{ Umur Tanaman (HSP) } \\
\hline & 6 & 12 & 18 & 24 & 30 & 36 & 42 & 48 & 54 & 60 \\
\hline Aerasi & \multicolumn{10}{|c|}{ Presentase setek hidup (\%) } \\
\hline Tanpa Aerasi & 100 & $99.8 \mathrm{a}$ & 98.6 & 96.1 & 95.2 & $94.2 \mathrm{a}$ & 90.8 & 81.1 & 75 & 57.7 \\
\hline Aerasi & 99.4 & $95.5 b$ & 90.3 & 87.7 & 78.3 & $68.8 \mathrm{~b}$ & 61.7 & 54.5 & 48.4 & 39.4 \\
\hline Uji F & tn & $*$ & tn & tn & tn & $*$ & tn & tn & tn & tn \\
\hline IBA (mgL-1) & \multicolumn{10}{|c|}{ Presentase setek hidup (\%) } \\
\hline IBA 0.0 & 100 & 98.4 & 94.7 & 94.4 & 90.3 & 86.6 & 84.4 & 77.8 & 71.3 & 56.9 \\
\hline IBA 0.5 & 99.7 & 96.3 & 95.3 & 88.8 & 85.3 & 81.9 & 80 & 72.8 & 67.5 & 51.6 \\
\hline IBA 1.0 & 99.4 & 96.9 & 94.4 & 93.8 & 88.4 & 81.6 & 70 & 61.9 & 56.9 & 43.4 \\
\hline IBA 2.0 & 99.7 & 98.4 & 93.4 & 90.6 & 82.8 & 75.9 & 70 & 58.8 & 51.3 & 42.2 \\
\hline Uji F & tn & tn & tn & tn & tn & tn & tn & tn & tn & tn \\
\hline Interaksi & tn & tn & tn & tn & tn & tn & tn & tn & tn & tn \\
\hline
\end{tabular}

Keterangan: Angka-angka yang diikuti oleh huruf yang sama pada kolom yang sama untuk masing-masing perlakuan aerasi dan IBA tidak berbeda nyata pada taraf $\alpha$ 5\% (uji selang berganda Duncan).

\section{KESIMPULAN}

Perlakuan aerasi dan IBA berpengaruh terhadap induksi akar dan tunas setek tanaman pohpohan dalam penelitian ini. Interaksi perlakuan aerasi dan IBA berpengaruh nyata pada jumlah akar, panjang akar, jumlah tunas, dan panjang tunas. Interaksi perlakuan aerasi dan IBA memberikan pengaruh lebih baik pada kombinasi perlakuan tanpa aerasi dan IBA 0.5, 1.0, dan 2.0 $\mathrm{mgL}^{-1}$ untuk parameter jumlah akar, kombinasi tanpa aerasi dan IBA $0.0 \mathrm{mgL}^{-1}$ pada parameter panjang akar, kombinasi aerasi dan IBA $0.0 \mathrm{mgL}^{-}$ 1 pada parameter jumlah tunas saat 6 HSP. Pada 30 HSP, secara keseluruhan semua kombinasi perlakuan memberikan pengaruh lebih baik pada parameter jumlah tunas kecuali kombinasi perlakuan tanpa aerasi dan IBA $2.0 \mathrm{mgL}^{-1}$. Interaksi perlakuan menunjukan pengaruh lebih baik pada kombinasi tanpa aerasi dengan semua taraf IBA dan tanpa aerasi dengan IBA $0.0 \mathrm{mgL}^{-1}$ pada parameter panjang tunas.

Pemberian aerasi pada media tumbuh tidak memberikan hasil lebih baik dibandingkan tanpa aerasi pada peubah persentase setek bertunas, jumlah tunas, panjang tunas, jumlah akar dan panjang akar. Penggunaan IBA terbukti mampu memacu pembentukan akar namun tidak berpengaruh pada persentase setek berakar. Penggunaan IBA $0.5,1.0$, dan $2.0 \mathrm{mgL}^{-1}$ tidak menghasilkan jumlah akar yang berbeda nyata pada kelompok perlakuan media tanpa aerasi. IBA $0.0 \mathrm{mgL}^{-1}$ menghasilkan akar lebih panjang dibandingkan perlakuan lainnya.

\section{DAFTAR PUSTAKA}

Amalia, R., I. Fidrianny, Sukrasno. 2006. Telaah kandungan kimia ekstrak etil asetat daun pohpohan (Pilea trinervia Wight.). [Skripsi]. Bandung (ID): Institut Teknologi Bandung.

Andarwulan, N., R. Batari, D.A. Sandrasari, B. Bolling, H. Wijaya. 2010. Falvonoid content and antioxidant activity of vegetaables from Indonesia. Food Chemistry. 121:1231-1235.

Cerveny, C., J. Gibson. 2005. Crop Cultivation: Root Hormones. www. gpnmag.com.

Desminarti, S. 2001. Kajian serat dan antioksidan alami beberapa jenis sayuran serta daya serap dan retetni antioksidan pada tikus percobaan. [Skripsi]. Bogor (ID): Institut Pertanian Bogor.

Gibson, J.L. 2001. Plant Propagation: Basic Principles and Methodology. Floriculture Research. North Carolina State University.

Hartmann, H.T., D.E. Kester, F.T. Davies, Jr., R.L. Geneve. 1997. Plant propagation principles and practices. 6th ed. Prentice Hall, Englewood Cliffs, N.J. pp. 770.

Hoagland, D.R., D.I. Arnon. 1950. The waterculture method for growing plants without soil. California Agricultural Experiment Station. University of California. 
Imelda, M., Aida W., Y.S. Poerba. 2008. Regenerasi tunas dari kultur tangkai daun Iles-iles (Amorphophallus muelleri Blume). Biodiversitas. 9 (3) : 173-176.

Jackson, M.B., Colmer, T.D. 2005. Response and adaptation by plants to flooding stress. Annals of Botany. 96: 501-505.

Kester, D.E., Hartmann TH, Davier FT. 1990. Plant propagation: Principles and Practices. 5th edition. Prentice Hall, Singapore, p. 647.

Khudry, A. 2014. Aktivitas antibakteri ekstrak daun pohpohan (Pilea trinervia W.) terhadap Escherichia coli dan Staphylosossus aureus. Skripsi. Universitas Atma Jaya Yogyakarta. Larsen FE, Guse WE. 1997. Propagating deciduous and evergreen shrubs, trees and vines with stem cuttings. A Pacific Northwest Cooperative Extetnion Publication, Washington, USA, p. 10.

Mahyar, U.W. 1994. Pilea lindley. Bogor (ID): Plant Resources of South-East Asia No.8. PROSEA: Vegetables.

Muslimawati, Nicha. 2014. Pertumbuhan setek batang pohpohan (Pilea trinervia wight.) pada umur tanaman, bagian batang, dan media tanam yang berbeda. [Skripsi]. Itntitut Pertanian Bogor. Bogor.

Newton, A.C., Mesen J.F., J.Mc.P. Dick, R.R.B. Leakey. 1992. Low technology propagation of tropical trees: Rooting physiology and practical implicatiotn. in: Mass production technology for genetically improved fast growing forest tree species. AFOCEL, Nangis, France, 2: 417-424.
Nickell, L.G. 1982. Plant Growth Regulators: agricultural uses. Springer-Verlag Berlin Heidelberg New York (USA).

Rahmawati, A. 2014. Interaksi intetnitas naungan dan dosis pemupukan pada pertumbuhan dan hasil pohpohan (Pilea trinervia wight.). [Skipsi]. Bogor (ID): Institut Pertanian Bogor.

Sato, T., T. Harada, K. Ishizawa . 2002. Stimulation of glycolysis in anaerobic elongation of pondweed (Potamogeton distinctus) turion. J. Exp. Bot. 53:184756.

Soetiarso, I.T. 2010. Sayuran indogenous alternatif bahan pagan bernilai gizi tinggi. Iptek Holtikultura. Balai Penelitian Tanaman Sayuran. Kementrian Pertanian.

Somantri, I. 2006. Pentingnya melestarikan sayuran indigenous (indigenes). Makalah disampaikan pada pelatihan "Promosi Pemanfaatan Sayuran Indigenous untuk Peningkatan Nutrisi Keluarga melalui Kebun Pekarangan. Jakarta 17-19 April 2006. $6 \mathrm{hlm}$.

Tabei, Y., T. Kanno, T. Nishio. 1991. Regulation of organogenesis and somatic embryogenesis by auxin in melon, Cucumis melo L. Plant Cell Reports. Vol $10: 225-229$.

Wulandari, R.C., R. Linda, Mukarlina. 2013. Pertumbuhan setek melati putih (Jasminum sambac (L) W. Ait.). dengan pemberian air kelapa dan IBA (Indole Butyric Acid ). Protobiont. Vol 2(2):3943.

Zulkarnain, H. 2010. Dasar-Dasar Holtikultura. Jakarta (ID) : Bumi Aksara. 